Innowacje w Pielęgniarstwie i Naukach o Zdrowiu

$1(1) / 2016$

ISSN: 2451-1846

DOI: http://dx.doi.org/10.21784/IwP.2016.002

Bogusława Serzysko ${ }^{1,2}$, Joanna Janik ${ }^{3}$, Joanna Świerczek ${ }^{2}$

${ }^{1}$ Śląskie Centrum Chorób Serca w Zabrzu, Katedra Kardiologii, Wad Wrodzonych Serca i Elektroterapii z Oddziałem Kardiologii Dziecięcej Śląskiego Uniwersytetu Medycznego w Katowicach

${ }^{2}$ Wyższa Szkoła Planowania Strategicznego w Dąbrowie Górniczej, Wydział SpołecznoMedyczny

${ }^{3}$ Studentka, Wyższa Szkoła Planowania Strategicznego w Dąbrowie Górniczej, Wydział Społeczno-Medyczny

\title{
Program profilaktyczny SCORE w zakresie chorób układu krążenia
}

\author{
The SCORE prophylactic for diseases \\ of the circulatory system
}

\section{Streszczenie:}

Wstęp. Choroby sercowo-naczyniowe odpowiadają za około 50\% zgonów w Europie. W Polsce umieralność z powodu udaru mózgu i zawału serca jest około 1,5 do 3 razy wyższa, niż w krajach starej Unii Europejskiej. Niepokojący jest fakt, iż wyższa umieralność w stosunku do krajów UE dotyczy w znacznym stopniu ludzi młodych i w średnim wieku. Najskuteczniejszą metodą ograniczenia zachorowalności oraz zmniejszenia umieralności jest profilaktyka pierwotna.

Cel badań. Celem badań była ocena ryzyka wystąpienia incydentu sercowonaczyniowego według algorytmu SCORE wśród populacji pacjentów Podstawowej Opieki Zdrowotnej (POZ) biorących udział w Programie Profilaktyki Chorób Układu Krążenia w województwie śląskim. 
Materiał i metoda. Program profilaktyczny skierowany był do osób obciążonych czynnikami ryzyka znajdujących się na liście lekarza poradni POZ w grupie wiekowej najbardziej zagrożonych chorobami układu krążenia, tj. od 35 do 55 roku życia. Badania przeprowadzono przy zastosowaniu Karty Badania Profilaktycznego od stycznia do grudnia 2014 roku. Badaniami objęto 142 pacjentów (86 kobiet - 60,56\% i 56 mężczyzn 39,44\%).

Wyniki. Czynnikami wpływającymi na zwiększoną zachorowalność na choroby sercowo-naczyniowych wśród badanej populacji była: otyłość, która występowała u 21,13\% badanej populacji, zbyt niska aktywność fizyczna $83,1 \%$, cukrzyca $4,23 \%$, nadciśnienie tętnicze $21,83 \%$, podwyższone wartości cholesterolu $(63,38 \%)$, LDL $(60,56 \%)$, trójglicerydów $(19,72 \%)$ czy palenie papierosów $(61,11 \%)$.

Wnioski. W badanej zbiorowości na przykładzie SCORE przeważały osoby o umiarkowanym ryzyku (56,34\%) wystąpienia incydentu sercowonaczyniowego w ciągu najbliższych dziesięciu lat, 26,06\% z małym ryzykiem oraz $14,79 \%$ ze zwiększonym ryzykiem. Tylko u 2,82\% respondentów stwierdzono znaczne ryzyko wystąpienia choroby. W wyniku badania profilaktycznego u 5,63\% pacjentów rozpoznano chorobę układu krążenia, którzy zostali skierowani na dalszą diagnostykę lub leczenie.

\section{Abstract:}

Introduction. Cardiovascular diseases are responsible for about 50\% of deaths in Europe. In Poland, mortality from stroke and heart attack is from approximately 1.5 to 3 times higher than in the old European Union. Alarming is the fact that the higher mortality compared to the countries of the EU regards largely the young and middle-aged. The most effective method to reduce morbidity and decrease mortality is primary prevention.

Aim. The aim of the study was to assess the risk of a cardiovascular event according to SCORE algorithm with the population of Primary Health Care (PHC) patients participating in the Program for the Prevention of Cardiovascular Diseases in Silesian Province.

Material and methods. The preventive program was aimed at people with risk factors included in the list PHC medical clinic in the age group with the highestrisk of cardiovascular disease, ranging from 35 to 55 years of age. The research was carried out with the use of the Charter of Prophylactic Examination from January to December 2014. The study included 142 patients (86 women $-60.56 \%$ and 56 men $39.44 \%$ ). 
Results. The factors affecting the increased incidence of cardiovascular disease among the studied population was obesity, which appeared in $21.13 \%$ of the population surveyed, very low physical activity $83.1 \%$, diabetes $4.23 \%$, hypertension $21.83 \%$, increased values of cholesterol $(63.38 \%)$, LDL cholesterol (60.56\%) TG (19.72\%) and smoking (61.11\%).

Conclusions. In the study population as an example of SCORE there were mostly people with moderate risk (56.34\%) of a cardiovascular event within the next ten years, $26.06 \%$ of low risk and $14.79 \%$ with an increased risk. Only in $2.82 \%$ of respondents a significant risk of the disease was identified. In the result of preventive examinations $5.63 \%$ of patients were diagnosed with cardiovascular disease and referred for further evaluation or treatment.

Słowa kluczowe: profilaktyka, SCORE, otyłość, palenie papierosów.

Keywords: prevention, SCORE, obesity, smoking

\section{Wstęp}

Choroby sercowo-naczyniowe (ChSN) są jednym z zagrożeń dla zdrowia Polaków. Stanowią główną przyczynę chorobowości, umieralności oraz niepełnosprawności zarówno w Polsce, jak i w większości krajów rozwiniętych. Stanowią poważny problem dla systemu opieki zdrowotnej i polityki zdrowotnej, ponieważ wpływają na rosnące koszty tej opieki [1]. Choroby te odpowiadają za około 50\% zgonów w Europie. W Polsce umieralność z powodu udaru mózgu i zawału serca jest od około 1,5 do 3 razy wyższa, niż w krajach starej Unii Europejskiej. Niepokojący jest fakt, iż wyższa umieralność w stosunku do krajów UE dotyczy w znacznym stopniu ludzi młodych i w średnim wieku. Najskuteczniejszą metodą ograniczenia zachorowalności oraz zmniejszenia umieralności jest profilaktyka pierwotna [2].

Nieprzestrzeganie prozdrowotnego stylu życia jest czynnikiem ryzyka współczesnych chorób cywilizacyjnych. Programy profilaktyczne są istotnym źródłem informacji o stanie zdrowia populacji. Przyczyniają się do redukcji chorobowości, umieralności z powodu chorób układu krążenia (ChUK) [3]. Działania profilaktyki pierwotnej 
dotyczą działań podejmowanych po stwierdzeniu podwyższonego poziomu czynników ryzyka sercowego, obejmując zalecenia modyfikacji stylu życia i edukację zdrowotną, zmierzające do ograniczenia lub usunięcia czynników ryzyka. Zapobieganie nowym zachorowaniom poprzez zmniejszenie narażenia na czynniki ryzyka ChUK stanowi najlepszą metodę redukcji zachorowań oraz umieralności z powodu tych schorzeń. Oszacowano, iż dzięki zmniejszeniu narażenia na czynniki ryzyka i innym działaniom prowadzonym w ramach prewencji pierwotnej można zapobiec $60-70 \%$ zgonów na skutek ChSN w krajach wysoko rozwiniętych [4].

Do rozwoju chorób układu krążenia prowadzi wiele czynników ryzyka, które możemy podzielić na modyfikowalne i te, których modyfikacja jest niemożliwa. Do drugiej grupy zalicza się płeć męską, zaawansowany wiek i predyspozycje genetyczne, a do najważniejszych czynników potencjalnie modyfikowalnych należą: palenie papierosów, nadciśnienie tętnicze, otyłość, zaburzenia gospodarki lipidowej i węglowodanowej, niska aktywność fizyczną oraz stres. Podłożem tych chorób jest zwykle miażdżyca, która przez wiele lat postępuje bezobjawowo, a jej występowanie związane jest między innymi ze stylem życia i czynnikami, które można modyfikować.

Zapobieganie chorobom sercowo-naczyniowym obejmuje przestrzeganie zasad zdrowego stylu życia, zwalczanie czynników ryzyka. Jak wykazały badania epidemiologiczne obserwowane w ciągu ostatnich dekad zmniejszenie umieralności z przyczyn sercowonaczyniowych jest w głównej mierze wynikiem poprawy stylu życia, leczenia nadciśnienia tętniczego, zaburzeń lipidowych oraz cukrzycy, a także wdrożenia farmakoterapii prewencyjnej. Te oddziaływania odpowiadają za blisko $80 \%$ sukcesu współczesnej prewencji chorób układu krążenia, jakim jest zmniejszenie umieralności z ich powodu. Doświadczenia płynące $\mathrm{z}$ krajów europejskich oraz Stanów Zjednoczonych wskazują, iż programy profilaktyczne w znacznym stopniu przyczyniają się do redukcji zgonów obywateli tych państw. Zaniechania w pierwotnej prewencji chorób układu krążenia mają bardzo 
niekorzystne skutki, gdyż wiadomo, że działania profilaktyczne są nie tylko skuteczne, ale uzasadnione ekonomicznie [2].

Celem pracy była ocena ryzyka wystąpienia incydentu sercowonaczyniowego według algorytmu SCORE w populacji pacjentów wybranej Poradni Medycyny Rodzinnej POZ uczestniczących w Programie Profilaktyki Chorób Układu Krążenia finansowanym przez Narodowy Fundusz Zdrowia (NFZ) w województwie śląskim.

\section{Materiał i metody}

Program profilaktyczny realizowany i finansowany w ramach kontraktu z NFZ na realizację świadczeń w zakresie lekarza POZ skierowany był do osób obciążonych czynnikami ryzyka znajdujących się na liście lekarza poradni POZ w grupie wiekowej najbardziej zagrożonych chorobami układu krążenia, tj. od 35 do 55 roku życia. Uprawnionymi do uzyskania świadczeń w powyższym zakresie były osoby będące w danym roku kalendarzowym w 35, 40, 45, 50 i 55 roku życia, u których nie została dotychczas rozpoznana choroba układu krążenia i które w okresie ostatnich 5 lat nie korzystały ze świadczeń udzielanych w ramach Programu (również u innych świadczeniodawców).

Świadczenia w ramach Programu były udzielane bez skierowania. Na badania pacjenci byli zapraszani imiennie, osobiście, telefonicznie, bądź w trakcie wizyty u lekarza. Zaproszenia zamieszczono również $\mathrm{w}$ formie plakatu w Przychodni Specjalistycznej oraz na stronie internetowej tejże placówki i w gazecie lokalnej.

Badania przeprowadzono przy zastosowaniu wywiadu zgodnie z Kartą Badania Profilaktycznego (załącznik do pisma Prezesa NFZ z dnia 23 września 2013 r.). Badania zostały przeprowadzone od stycznia do grudnia 2014 roku. Badaniami objęto 142 pacjentów (86 kobiet i 56 mężczyzn). Z zakwalifikowanych do programu 555 osób zgłosiło się tylko 142 pacjentów, co stanowiło 25,6\%; czyli na zaproszenie nie odpowiedziało aż 74,4\% osób. 
Cała badana grupa została podzielona na dwie duże grupy według kryterium płci. Każda z tych grup osób została następnie podzielona na dwie podgrupy: do pierwszej podgrupy zaliczono osoby, dla których wiek nie stanowi czynnika ryzyka chorób układu krążenia (zarówno w przypadku kobiet i mężczyzn są to osoby do 45 lat) oraz osoby, dla których wiek stanowić może czynnik ryzyka chorób układu krążenia (dotyczy również osób obu płci w wieku powyżej 46 lat).

Dla każdej z wyróżnionych podgrup, na podstawie analizy wyników badania fizykalnego oraz badania biochemicznego, ustalono liczbę osób, dla których wymienione czynniki stanowią czynnik ryzyka oraz liczbę osób, dla których czynniki te nie stanowią czynnika ryzyka. Obliczono także ryzyko incydentu sercowo-naczyniowego według algorytmu SCORE. Jednak nie wszystkie czynniki wpływające na występowanie ryzyka sercowo-naczyniowego przedstawiono $\mathrm{w}$ tej pracy. Wyłoniono tylko te najważniejsze, które wpływają na zachorowalność, a mogą zostać zmniejszone poprzez prewencję i edukację pacjentów. Zaliczają się do nich otyłość, aktywność fizyczna i palenie papierosów.

Z otrzymanych wyników wynika, iż 9,3\% ogółu kobiet znajduje się w grupie ryzyka ze względu na wiek (45 lat i więcej), a 90,7\% jest poza grupą ryzyka. Natomiast $64,29 \%$ ogółu mężczyzn znajduje się w grupie ryzyka ze względu na wiek (45 lat i więcej), a 35,71\% pozostaje poza grupą ryzyka.

W grupie kobiet, które ze względu na wiek nie należą do grupy ryzyka, odnotowano dodatkowe obciążenie w postaci przypadków rozpoznania u ojca lub matki zawału serca lub udaru mózgu. I tak, u 12 kobiet spoza grupy ryzyka ze względu na wiek ojciec miał rozpoznany zawał serca (13,95\% ogółu kobiet), u 4 kobiet ojciec miał rozpoznany udar mózgu $(4,65 \%)$, u 5 matka miała rozpoznany zawał serca (5,91\%); w przypadku jednej kobiety rozpoznano udar mózgu u matki $(1,16 \%)$. Natomiast w grupie kobiet należących ze względu na wiek do grupy ryzyka w jednym przypadku stwierdzono udar mózgu u matki $(1,16 \%)$, co przedstawia tabela 1. 
Tabela 1. Charakterystyka badanej grupy ze względu na płeć oraz wiek pod kątem obciążenia rodzinnego

\begin{tabular}{|c|c|c|c|c|c|c|}
\hline \multirow{2}{*}{ Specyfikacja } & \multicolumn{3}{|c|}{ Kobiety } & \multicolumn{3}{|c|}{ Mężczyźni } \\
\hline & $\begin{array}{l}\text { do } \\
45 \\
\text { lat }\end{array}$ & $\begin{array}{l}46 \text { lat i } \\
\text { więcej }\end{array}$ & Razem & $\begin{array}{l}\text { do } \\
45 \\
\text { lat }\end{array}$ & $\begin{array}{l}46 \text { lat i } \\
\text { więcej }\end{array}$ & Razem \\
\hline Liczba & 78 & 8 & 86 & 20 & 36 & 56 \\
\hline $\begin{array}{l}\text { Zdiagnozowany zawał } \\
\text { mięśnia sercowego } \\
\text { u ojca }\end{array}$ & 12 & 0 & 12 & 1 & 3 & 4 \\
\hline $\begin{array}{l}\text { Zdiagnozowany udar } \\
\text { u ojca }\end{array}$ & 4 & 0 & 4 & 0 & 2 & 2 \\
\hline $\begin{array}{l}\text { Zdiagnozowany zawał } \\
\text { mięśnia sercowego } \\
\text { u matki }\end{array}$ & 5 & 0 & 5 & 0 & 2 & 2 \\
\hline $\begin{array}{l}\text { Zdiagnozowany udar } \\
\text { u matki }\end{array}$ & 1 & 1 & 2 & 0 & 2 & 2 \\
\hline
\end{tabular}

Źródło: opracowanie własne.

Z powyższych danych wynika, że u kobiet, które ze względu na wiek nie należą do grupy ryzyka, ale których rodzice mieli rozpoznany zawał serca lub udar mózgu, ryzyko choroby układu krążenia można uznać za podwyższone [5].

W grupie mężczyzn nie należących ze względu na wiek do grupy ryzyka odnotowano tylko jeden przypadek rozpoznanego zawału serca u ojca (1,79\% ogółu mężczyzn). Wszystkie pozostałe przypadki zachorowań ojca lub matki na zawał serca lub udar mózgu dotyczą mężczyzn należących ze względu na wiek do grupy ryzyka. Tak więc 
odnotowano 3 przypadki zawału serca u ojca (5,36\% ogółu mężczyzn), po 2 przypadki udaru mózgu u ojca, zawału serca u matki i udaru mózgu u matki (po 3,57\%). Jak widać, w przypadku mężczyzn genetyczny czynnik ryzyka pojawia się zazwyczaj w grupie mężczyzn w wieku, w którym oni sami znajdują się już w grupie ryzyka, a czynnik dziedziczny jedynie pogłębia to ryzyko.

Natomiast w badanej grupie nadciśnienie tętnicze wystąpiło jako czynnik ryzyka chorób układu krążenia u 31 osób (co stanowi 21,83\% ogółu badanych osób), a u 111 osób (78,17\%) nadciśnienie tętnicze nie stanowiło czynnika ryzyka ChUK. Jak wynika z przedstawionych danych w tabeli $2 \mathrm{w}$ obu wyróżnionych ze względu na wiek podgrupach kobiet odnotowano istotnie większe udziały kobiet, dla których nadciśnienie tętnicze nie stanowi czynnika ryzyka chorób układu krążenia: w grupie kobiet w wieku do 45 lat (w tej grupie wiek nie jest jeszcze czynnikiem ryzyka ChUK) udział osób bez podwyższonych wartości ciśnienia tętniczego wynosi 93,59\%, w grupie kobiet w wieku powyżej 45 lat (w tej grupie wiek jest czynnikiem ryzyka ChUK) udział ten wynosi $62,50 \%$. W grupie mężczyzn w wieku do 45 lat (w tej grupie wiek nie jest czynnikiem ryzyka ChUK), co czwarta osoba ma nadciśnienie tętnicze, natomiast w grupie wiekowej powyżej 45 lat (w tej grupie wiek jest w przypadku mężczyzn czynnikiem ryzyka ChUK), co druga. Jak widać, udział mężczyzn z nadciśnieniem tętniczym jest w obu ich podgrupach wyższy niż w odpowiadających im podgrupach kobiet. Zróżnicowanie udziałów okazało się na tyle duże, że wystąpiła znamienność statystyczna $p<0,05$, co uwidacznia tabela 2. 
Tabela 2. Nadciśnienie tętnicze jako czynnik ryzyka.

\begin{tabular}{|c|c|c|c|}
\hline \multirow{2}{*}{ Specyfikacja } & \multicolumn{3}{|c|}{ Nadciśnienie tętnicze } \\
\hline & $\begin{array}{c}\text { Nie jako czyn- } \\
\text { nik ryzyka }\end{array}$ & $\begin{array}{c}\text { Jako czynnik } \\
\text { ryzyka }\end{array}$ & Razem \\
\hline \multicolumn{4}{|c|}{ Dane empiryczne } \\
\hline Kobiety w wieku do 45 lat & 73 & 5 & 78 \\
\hline Kobiety w wieku ponad 45 lat & 5 & 3 & 8 \\
\hline Mężczyźni w wieku do 45 lat & 15 & 5 & 20 \\
\hline Mężczyźni w wieku ponad 45 lat & 18 & 18 & 36 \\
\hline Razem & 112 & 31 & 142 \\
\hline \multicolumn{4}{|c|}{ Oczekiwane wartości } \\
\hline Kobiety w wieku do 45 lat & 61 & 17 & 78 \\
\hline Kobiety w wieku ponad 45 lat & 6 & 2 & 8 \\
\hline Mężczyźni w wieku do 45 lat & 16 & 4 & 20 \\
\hline
\end{tabular}




\begin{tabular}{|l|c|c|c|}
\hline Mężczyźni w wieku ponad 45 lat & 28 & 8 & 36 \\
\hline Razem & $\mathbf{1 1 1}$ & $\mathbf{3 0}$ & $\mathbf{1 4 2}$ \\
\hline \multicolumn{2}{|c|}{ Obliczenia chi-kwadrat } & \\
\hline Kobiety w wieku do 45 lat & 2,37285 & 8,49632 & 10,86917 \\
\hline Kobiety w wieku ponad 45 lat & 0,25127 & 0,89970 & 1,15097 \\
\hline Mężczyźni w wieku do 45 lat & 0,02569 & 0,09200 & 0,11770 \\
\hline Mężczyźni w wieku ponad 45 lat & 3,65436 & 13,08496 & 16,73932 \\
\hline Razem & $\mathbf{6 , 3 0 4 1 7}$ & $\mathbf{2 2 , 5 7 2 9 9}$ & $\mathbf{2 8 , 8 7 7 1 6}$ \\
\hline Wartość krytyczna chi-kwadrat & & & \\
\hline
\end{tabular}

Źródło: opracowanie własne.

Natomiast otyłość w badanej grupie jako czynnik ryzyka wystąpiła u 30 osób (co stanowiło 21,13\% ogółu badanych osób), nie była natomiast czynnikiem ryzyka ChUK w przypadku 112 osób (78,87\% ogółu badanych).

W każdej z badanych podgrup udziały osób, dla których otyłość stanowiła czynnik ryzyka i dla których nie była takim czynnikiem ryzyka, były porównywalne. Znamienność statystyczna nie wystąpiła (chi kwadrat obliczone dla danych empirycznych wynosi tylko 0,71428, przy chi kwadrat krytycznym równym 7,81473; p>0,05), co przedstawia tabela 3 . 
Tabela 3. Otyłość jako czynnik ryzyka.

\begin{tabular}{|c|c|c|c|}
\hline \multirow[b]{2}{*}{ Specyfikacja } & \multicolumn{3}{|c|}{ Otyłość } \\
\hline & $\begin{array}{c}\text { Nie jako czyn- } \\
\text { nik ryzyka }\end{array}$ & $\begin{array}{c}\text { Jako czynnik } \\
\text { ryzyka }\end{array}$ & Razem \\
\hline \multicolumn{4}{|c|}{ Dane empiryczne } \\
\hline Kobiety w wieku do 45 lat & 62 & 16 & 78 \\
\hline Kobiety w wieku ponad 45 lat & 7 & 1 & 8 \\
\hline Mężczyźni w wieku do 45 lat & 16 & 4 & 20 \\
\hline Mężczyźni w wieku ponad 45 lat & 27 & 9 & 36 \\
\hline Razem & 112 & 30 & 142 \\
\hline \multicolumn{4}{|c|}{ Oczekiwane wartości } \\
\hline Kobiety w wieku do 45 lat & 62 & 16 & 78 \\
\hline Kobiety w wieku ponad 45 lat & 6 & 2 & 8 \\
\hline Mężczyźni w wieku do 45 lat & 16 & 4 & 20 \\
\hline Mężczyźni w wieku ponad 45 lat & 28 & 8 & 36 \\
\hline Razem & 112 & 30 & 142 \\
\hline \multicolumn{4}{|c|}{ Obliczenia chi-kwadrat } \\
\hline Kobiety w wieku do 45 lat & 0,00373 & 0,01392 & 0,01764 \\
\hline Kobiety w wieku ponad 45 lat & 0,07548 & 0,28181 & 0,35729 \\
\hline Mężczyźni w wieku do 45 lat & 0,00322 & 0,01202 & 0,01524 \\
\hline Mężczyźni w wieku ponad 45 lat & 0,06847 & 0,25563 & 0,32411 \\
\hline Razem & 0,15090 & 0,56338 & 0,71428 \\
\hline Wartość krytyczna chi-kwadrat & \multicolumn{3}{|c|}{$7,81473 p>0,05$} \\
\hline
\end{tabular}

Źródło: opracowanie własne. 
Również otyłość brzuszna w całej badanej grupie nie stanowi czynnika ryzyka u 101 osób (71,13\% ogółu badanych), natomiast jest czynnikiem ryzyka w przypadku 41 pozostałych osób $(28,87 \%)$. Znamienność statystyczna nie wystąpiła (chi kwadrat obliczone dla danych empirycznych wynosi tylko 3,72384, przy chi kwadrat krytycznym równym 7,$81473 ; p>0,05$ ). Jak wynika $z$ otrzymanych wyników, w przypadku grup osób, które ze względu na wiek nie należą do grup ryzyka, u kobiet częściej aniżeli u mężczyzn występuje otyłość brzuszna:, co trzecia kobieta w wieku do 55 lat ma otyłość brzuszną, wśród mężczyzn w wieku do 45 lat - tylko, co szósty lub siódmy.

W grupach osób, które ze względu na wiek należą do grup ryzyka, sytuacja przedstawia się odwrotnie: tylko, co ósma kobieta w wieku powyżej 45 lat i prawie, co trzeci mężczyzna w wieku powyżej 45 lat cierpi na otyłość brzuszną. Uzyskane wyniki, aczkolwiek dość zróżnicowane, nie wykazały znamienności statystycznej.

Mała aktywność fizyczna ogółem w całej badanej grupie również nie stanowi czynnika ryzyka ChUK tylko u 24 osób (16,90\% ogółu badanych), jest natomiast takim czynnikiem u 118 osób (83,10\%). Uzyskane wyniki nie wykazały znamienności statystycznej, co oznacza, że niezależnie od tego, czy dana osoba ze względu na wiek znajduje się w grupie ryzyka ChUK czy nie, czynnikiem ryzyka jest dla niej w dużym stopniu mała aktywność fizyczna. I tak, w przypadku kobiet w wieku do 45 lat aż 83,33\% osób prowadzi małą aktywność fizyczną, w przypadku kobiet w wieku powyżej 45 lat - wszystkie, w przypadku mężczyzn w wieku do 45 lat mało aktywny tryb życia prowadzi $85 \%$ osób, a w przypadku mężczyzn w wieku powyżej 45 lat -77,78\%.

W przypadku 136 osób (95,77\% ogółu badanych) cukrzyca nie jest czynnikiem ryzyka, tylko w przypadku 6 osób jest $(4,23 \%)$. U mężczyzn cukrzyca jest istotnie mniejszym czynnikiem ryzyka aniżeli w przypadku kobiet: podwyższonej ponad $125 \mathrm{mg} / \mathrm{dl}$ glikemii na czczo nie stwierdzono ani u jednego mężczyzny w wieku do 45 lat, a w wieku powyżej 45 lat na cukrzycę cierpi tylko, co dziewiąta osoba. W przypadku kobiet $\mathrm{w}$ wieku do 45 lat cukrzycę stwierdzono u jednej 
osoby, natomiast w grupie kobiet w wieku powyżej 45 lat - u co ósmej osoby. Uzyskane wyniki wykazały znamienność statystyczną (chi kwadrat obliczone dla danych empirycznych wynosi tylko 4,21786, przy chi kwadrat krytycznym równym 8,12352; p<0,05).

Do istotnych czynników ryzyka chorób układu krążenia należy też palenie papierosów. Z otrzymanych wyników badań wynika, że wśród respondentów aktualnie pali papierosy 14 kobiet z grupy wiekowej poniżej 55 lat; okres palenia waha się od 3 do 32 lat, przy czym kobiety te wypalają średnio 12 papierosów dziennie. W grupie kobiet ze względu na wiek zaliczonych do grupy ryzyka (powyżej 45 lat) aktualnie palą 4 osoby; okres palenia wynosi od 20 do 30 lat, a średnia liczba wypalanych dziennie papierosów jest równa 12,5 . W grupie mężczyzn, którzy ze względu na wiek nie zostali zaliczeni do grupy ryzyka (do 45 lat) aktualnie palą papierosy 4 osoby; okres palenia wynosi od 20 do 22 lat, średnia liczba wypalanych dziennie papierosów wynosi 17,5. W grupie mężczyzn zaliczonych ze względu na wiek do grupy ryzyka aktualnie pali 14 osób; czas palenia waha się od 12 do 40 lat, średnia liczba wypalanych dziennie papierosów jest równa 17,6. Ogółem w badanej grupie papierosy pali 36 osób (tj. co czwarta ankietowana osoba). Uzyskane wyniki wykazały znamienność statystyczną ( chi kwadrat obliczone dla danych empirycznych wynosi tylko 3,48579,przy chi kwadrat krytycznym równym 8,61569; $\mathrm{p}<0,05)$. W grupach osób nie zaliczonych ze względu na wiek do grup ryzyka udział osób niepalących jest około czterokrotnie wyższy niż udział osób aktualnie palących. W grupach osób, które ze względu na wiek zostały zaliczone do grup ryzyka, udziały te - w przypadku kobiet - wyrównały się (po 50\% kobiet palących aktualnie oraz kobiet nie palących); w przypadku mężczyzn natomiast nie pali aktualnie $38,89 \%$, pali zaś $-61,11 \%$.

Wszystkie osoby, które aktualnie palą papierosy, paliły je również w przeszłości. Jedynie jeden z mężczyzn przyznał, że w przeszłości nie palił, a zaczął palić papierosy w wieku 25 lat (obecnie ma 45 lat, a więc 20-letni okres palenia). Osoby, które w przeszłości nie 
paliły papierosów, nie palą ich również obecnie. Można więc, uznać, że nałóg palenia papierosów rozpoczyna się stosunkowo wcześnie i zazwyczaj trwa przez całe dalsze życie (w każdym razie jest to prawdą w przypadku badanej grupy osób).

Wszystkie badane osoby, za wyjątkiem jednej, mają przeprowadzane badania według programu SCORE zgodnie z ustalonym interwałem. Spośród nich 138 osób zostało skierowanych na edukację, a tylko 4 osoby nie zostały takiej edukacji poddane; w badaniu nie wyjaśniono, co było przyczyną nie kierowania tych czterech osób na edukację w zakresie chorób układu krążenia.

Tylko 8 osób (5,63\% ogółu badanych) zostało skierowane na dalszą diagnostykę oraz leczenie w poradni specjalistycznej. Było to sześciu mężczyzn, przy czym pięciu z nich ze względu na wiek znajdowało się w grupie ryzyka (wiek powyżej 45 lat), jeden natomiast nie należał do grupy ryzyka ze względu na wiek (liczył 40 lat). Na leczenie w poradni specjalistycznej skierowano również dwie kobiety, z których obie ze względu na wiek nie były zaliczane do grupy ryzyka chorób układu krążenia.

\section{Dyskusja}

Metoda badania SCORE staje się coraz bardziej popularna w naszym kraju. Pozwala bowiem, na diagnozę ryzyka chorób układu krążenia - poprzez analizę zagrożeń wywołujących ją czynników - o wiele wcześniej, nim pojawi się sama choroba. Chodzi przede wszystkim o takie czynniki, które są zależne od człowieka, tj. głównie styl życia (niewłaściwa dieta, używki, brak aktywności fizycznej itp.).

W pracy Ł. Wieruckiego i wsp. [6] przedstawiono wyniki zrealizowanego w latach 2000-2002 programu badań ryzyka zachorowania na choroby układu krążenia w wybranych 400 miejscowościach Polski. Celem programu było obniżenie zachorowalności i umieralności z powodu ChUK w naszym kraju. Realizatorzy badania wskazali, że cel ten może być osiągnięty poprzez „poprawę wykrywania i skuteczności leczenia nadciśnienia tętniczego, zaburzeń lipidowych i cukrzycy 
oraz zmniejszenie odsetka osób palących tytoń w środowiskach małych miast i wsi, szczególnie wśród mężczyzn oraz osób z niższym wykształceniem" [6]. Program zawierał następujące komponenty: interwencja społeczna, interwencja medyczna, budowa infrastruktury dla promocji zdrowia, interwencja antytytoniowa, edukacja dzieci w wieku szkolnym, szkolenie personelu medycznego, edukacja pacjentów. Łącznie przebadano 5171 osób. Wyniki badań nie okazały się zadowalające. Jak stwierdzają autorzy [7], „związane jest to z dużym rozpowszechnieniem czynników ryzyka sercowo-naczyniowego, niedostateczną ich wykrywalnością i skutecznością leczenia oraz niską świadomością zdrowotną społeczeństwa". Wskazano głównie na wysokie stężenie cholesterolu, nadwagę oraz otyłość, nieprawidłowe stężenie glukozy na czczo.

Wyniki przedstawione w [7] są dość zbieżne z wynikami badań własnych, z których również wynika dość duże rozpowszechnienie czynników ryzyka chorób układu krążenia. Należy przy tym zauważyć, że u wielu osób działa nie pojedynczy czynnik ryzyka, lecz cały ich zespół; znalazło to wyraz w liczbie tematów zajęć edukacyjnych, które tym badanym osobom były oferowane.

W pracy B. Gryglewskiej i wsp. [8] przedstawiono wyniki badań z 2006 roku przeprowadzonych w 2991 ośrodkach lecznictwa otwartego na terenie całego kraju. Badaniu poddawano osoby z nadciśnieniem tętniczym, które w okresie ostatnich 12 miesięcy nie było u nich kontrolowane. Badanie [8] wykazało istotne różnice wyników w porównaniu z innymi badaniami, co mogło jednak wynikać z niewłaściwego procesu leczenia osób z nadciśnieniem tętniczym (bez korzystania ze standardowych programów, jak np. SCORE, które pozwoliłyby na kompleksową diagnostykę czynników ryzyka chorób układu krążenia). Autorzy [8] wskazują, że niewłaściwie postawiona diagnoza może skutkować niedostateczną intensywnością leczenia i w konsekwencji jego nieskutecznością. 
W artykule B. Wożakowskiej-Kapłon i wsp. [9] przedstawiono szczegółowo metodykę stosowania algorytmu SCORE. Metodyka ta była zastosowana w badaniach własnych.

W pracy W. Mojsy [9] przedstawiono wyniki badań przeprowadzonych za pomocą algorytmu SCORE w województwie podlaskim na grupie 439 pacjentów w wieku 35-55 lat. Jako wielkość graniczną przyjęto 5\% (z algorytmu SCORE). Uzyskane przez autorkę [9] wyniki są dość zbieżne z wynikami badań własnych. W obu pracach stwierdzono, że w przypadku mężczyzn czynniki ryzyka chorób układu krążenia są silniej wyrażone, niż w przypadku kobiet.

W pracy W. Modrzejewskiego i W.J. Musiała [10] wskazano, że w ocenie zagrożenia osoby zdrowej chorobą układu krążenia należy kierować się oszacowaniem globalnego ryzyka obejmującego wszystkie rozpoznane czynniki ryzyka u danej osoby. Jak stwierdzają autorzy, „W ramach prewencji pierwotnej należy przede wszystkim dążyć do zmiany stylu życia i w razie potrzeby zastosować leczenie farmakologiczne". Natomiast w ramach prewencji wtórnej, u osób już chorujących, należy „nie tylko wyeliminować lub modyfikować konwencjonalne czynniki ryzyka, ale także często wdrożyć agresywną farmakoterapię tych czynników".

W badaniach własnych problematyka prewencji wtórnej nie stanowiła przedmiotu badań, a jedynie prewencja pierwotna, to jest zmiana stylu życia, co w sposób istotny może wpłynąć na częściową, chociaż eliminację czynników ryzyka chorób układu krążenia. Wspólne w obu pracach było podkreślenie tego, że badać należy nie tylko jeden, wybrany, czynnik ryzyka, lecz cały ich kompleks, gdyż dopiero takie ujęcia daje możliwość podjęcia skutecznych działań w celu zapobiegania chorobom układu krążenia. Jak się wydaje, algorytm SCORE stanowi bardzo dobre narzędzie diagnostyczne do określania czynników ryzyka u każdej osoby. Daje on bowiem kompleksową informację (jedna liczba) o tym, jakie jest prawdopodobieństwo wystąpienia incydentu sercowo-naczyniowego (i zgonu z tego powodu) w okresie najbliższych dziesięciu lat. Algorytm ten - poprzez jego 
dokładną analizę - może również pomóc w wyborze tych działań profilaktycznych, które będą najlepiej dopasowane do indywidualnej osoby.

\section{Wnioski}

Program profilaktyczny realizowany w POZ spełnia swoją rolę skriningową pozwalając na wczesną identyfikację osób zagrożonych chorobą, wykrywając ich czynniki ryzyka i obejmując profilaktyką pierwotną.

\section{Zalecenia dla praktyki pielęgniarskiej}

Konieczne jest dalsze prowadzenie działań zmierzających do wykrywania czynników ChUK. Zachodzi konieczność aktywnego poszukiwania form skutecznej profilaktyki oraz zwiększenia udziału w działaniach prewencyjnych osób z przedziału wiekowego 35-55 lat, kobiet i mężczyzn.

\section{Bibliografia/Bibliography:}

1. Jóźwiak P., Szmagaj A. Charakterystyka zachowań zdrowotnych mężczyzn po 50 roku życia w Poznaniu w odniesieniu do czynników ryzyka wystąpienia chorób sercowo-naczyniowych. Przegląd Lekarski. 2012; 69(10):935.

2. Żebrowska A., Hryniewiecki T. Profilaktyka pierwotna i wtórna w chorobach układu krążenia. Nowa Klinika. 2009;16(3-4):312.

3. Jóźwiak J. Ocena wybranych czynników ryzyka sercowonaczyniowego w ogólnopolskiej 5-letniej prospektywnej obserwacji kohorty pacjentów POZ. Badanie LIPIDOGRAM 5 lat. Wydawnictwo Politechniki Częstochowskiej, 2013; 5.

4. Pająk A. Stan profilaktyki kardiologicznej w Europie - wyniki badania EUOASPIRE - komentarz. Medycyna po Dyplomie. 2009;18(8):18. 
5. Podolec Piotr., Kopeć G. Jak powstają wytyczne Polskiego Forum Profilaktyki Chorób Układu Krążenia? Lekarz Rodzinny. 2011;16(9):814.

6. Wierucki Ł., Zdrojewski t., Mogilnaya I. Polski Projekt 400 Miast - wyniki badań pilotażowych. Nadciśnienie Tętnicze. 2004; 8(5): 307-318.

7. Gryglewski B., Sulicka J., Fornal M., Wizner B., Wilkins A., Grodzicki T. Ryzyko sercowo-naczyniowe chorych $\mathrm{z}$ niekontrolowanym nadciśnieniem tętniczym i jego ocena w lecznictwie otwartym w Polsce. Wyniki ogólnopolskiego programu RAPORT NT. Nadciśnienie Tętnicze. 2007;11(3):187-194.

8. Mojsa W. Analiza programu SCORE realizowanego w podstawowej opiece zdrowotnej w województwie podlaskim. Problemy Pielęgniarstwa. 2009;17(1):13-17.

9. Wożakowska-Kapłon B., Barylski M., Salwa P., Filipiak K.J., Siebert J. Zalecenia postępowania $\mathrm{w}$ dyslipidemii - propozycje algorytmu dla lekarzy rodzinnych. TULI/003/01-2013. URL: www.fmr.viamedica.pl (dostęp 12.05.2015 r.).

10. Modrzejewski W., Musiał W.J. Stare i nowe czynniki ryzyka sercowonaczyniowego - jak zahamować epidemię miażdżycy? Część I. Klasyczne czynniki ryzyka. Forum Zaburzeń Metabolicznych. 2010; 1(2):106-114. 